Chem. Commun., 2001, 383-384

DOI: $\underline{10.1039 / \mathrm{b} 009553 \mathrm{~m}}$

\title{
First anti-oestrogen in the cyclopentadienyl rhenium tricarbonyl series. Synthesis and study of antiproliferative effects
}

\author{
Gérard Jaouen, ${ }^{*}{ }^{a}$ Siden Top, ${ }^{a}$ Anne Vessières, ${ }^{a}$ Pascal Pigeon, ${ }^{a}$ Guy Leclercq ${ }^{b}$ and Ionna \\ Laios $^{b}$ \\ ${ }^{a}$ Laboratoire de Chimie Organométallique, Ecole Nationale Supérieure de Chimie de Paris, \\ UMR 7576, 11 rue Pierre et Marie Curie, 75231 Paris Cedex 05, France. E- \\ mail: jaouen@ext.jussieu.fr New mail address : gerard.jaouen@upmc.fr \\ ${ }^{b}$ Laboratoire de Cancérologie Mammaire, Institut Jules Bordet, Rue Héger Bordet, 1 \\ Brussels 1000,Belgium.E-mail: Icanmamm@ulb.ac.be
}

A route to the organometallic complex 8 is described, along with a study of its antiproliferative effects on breast cancer cell lines; in the examples studied, 8 behaves in a very similar manner to tamoxifen, suggesting new possibilities for applications in organometallic chemistry.

Tamoxifen 1 and its active metabolite, 4-hydroxytamoxifen 2 (Scheme 1) have been the subject of numerous studies owing to their efficacy in breast cancer treatment. ${ }^{1,2}$ Currently however, substitutes are being sought in order to obviate the effects of resistance build up, as well as to improve the therapeutic effectiveness of the current treatments. ${ }^{3,4}$ Our study is an attempt to potentiate the effects of these medications by introducing an organometallic-type modification to the base skeleton. Some organometallic complexes have in fact proven to be of interest either as antitumour agents, as in the case of the metallocenes of $\mathrm{Fe}$ and $\mathrm{Ti}^{5,6}$ or as radiopharmaceuticals, for example certain isotopes of Tc and Re. ${ }^{7,8}$ If the organometallic moiety could be incorporated into this molecule while still preserving its character as an antioestrogen vector, this would provide a route to new products of added interest in a variety of applications. The question of preservation of antagonist activity is not an idle concern; we have shown that merely substituting the phenyl in the $\beta$ position in $\mathbf{2}$ with a ferrocenyl group in 3 resulted in a significant drop in anti-oestrogenic effects in vitro on breast cancer cell lines, as well as in vivo, in nude mice. ${ }^{9,10}$ Here we show that by attaching to the diphenylethylene skeleton a moiety of $\operatorname{Re}(\mathrm{I})$, in the form of cyclopentadienyl $\operatorname{Re}(\mathrm{CO})_{3}$, small in size and difficult to oxidize, we obtain an anti-oestrogenic organometallic complex 
comparable to hydroxytamoxifen 2 but with the added advantage, owing to the presence of the metal Re, of allowing access to a new type of radiopharmaceutical compounds of ${ }^{99 \mathrm{~m}} \mathrm{Tc},{ }^{186} \mathrm{Re}$ or ${ }^{188} \mathrm{Re}$.

Compound $\mathbf{8}$ is prepared as shown in Scheme 2 starting from dihydroxybenzophenone 4 and the $\left(\eta^{5}-\mathrm{C}_{5} \mathrm{H}_{4} \mathrm{COEt}\right) \mathrm{Re}(\mathrm{CO})_{3}$ complex 6, itself prepared by a Friedel-Crafts reaction between cyclopentadienyl rhenium tricarbonyl and propionyl chloride. The aromatic ketone 4 is first reacted with $\mathrm{KH}$, to give the potassium salt, which reacts with dibromobutane. The monobrominated compound $\mathbf{5}$ is obtained in 35\% yield. A McMurry cross-coupling reaction ${ }^{11,12}$ between 5 and the organometallic compound $\mathbf{6}$ in the presence of $\mathrm{TiCl}_{4}$ and $\mathrm{Zn}$ in THF under reflux gives 7 in 62\% yield, and the latter when heated with dimethylamine in an autoclave produces $8(Z+E)$ in a yield of $64 \% . \dagger$ Separation of the isomers $8 \boldsymbol{Z}$ and $\mathbf{8 E}$ was done by reverse phase preparative HPLC. Identification of the isomers was ascertained by NMR on the $E$ isomer (effect between the protons $\mathrm{CH}_{3}-\mathrm{CH}_{2}$ and $\mathrm{C}_{6} \mathrm{H}_{4}-\mathrm{O}\left(\mathrm{CH}_{2}\right)_{4} \mathrm{~N}\left(\mathrm{CH}_{3}\right)_{2}$, as well as between $\eta^{5}-\mathrm{C}_{5} \mathrm{H}_{4}-\mathrm{Re}(\mathrm{CO})_{3}$ and $\left.\mathrm{C}_{6} \mathrm{H}_{4}-\mathrm{OH}\right)$. In contrast to what is observed in the ferrocene series, no rapid interconversion was noticed between $\mathbf{8 Z}$ and $\mathbf{8 E}$, then showing a similarity of the rhenium derivatives with tamoxifen.

The relative binding affinity values (RBA) of $\mathbf{8}$ were measured for the mixture $(Z+E)$ and for the individual isomers $Z$ and $E$ on the two oestrogen receptor subtypes ER $\alpha$ and ER $\beta$ using a competitive radiometric binding assay, with tritium-labeled oestradiol as tracer and protamine sulfate precipitation of the bound fraction of the tracer. ${ }^{13} \mathrm{ER} \alpha$ was prepared from sheep uterus and ER $\beta$, expressed in baculovirus, was obtained commercially from PanVera. The RBA values (mean of 2 or 3 experiments) found at $0{ }^{\circ} \mathrm{C}$ for 8 on $\mathrm{ER} \alpha$ are $8 \%$ for the mixture $\mathbf{8}(\boldsymbol{Z}+\boldsymbol{E}), 7.4 \%$ for $\mathbf{8 Z}$ and $5.2 \%$ for $\mathbf{8 E}$, thus showing only a slight difference between the two isomers. In contrast, the RBA value obtained for $\operatorname{ER} \beta$ is higher with $\mathbf{8 Z}$ $(17.8 \%)$ than for the mixture $8(Z+E)(6 \%)$ or the $E$ isomer $\mathbf{8 E}(5.6 \%)$. However it is important to notice that ER $\beta$ is a purified receptor devoid of the effectors naturally present in the receptor alpha preparation obtained from sheep. Nevertheless the affinity for both ER $\alpha$ and ER $\beta$ are still satisfactory even if these RBA values are lower than the values found for $\mathbf{2}$ $(\boldsymbol{Z}+\boldsymbol{E})$ on $\mathrm{ER} \alpha(38.5 \%)$ and $\mathrm{ER} \beta$ (20\%). This decrease probably reflects the greater steric crowding of $\left(\eta^{5}-\mathrm{C}_{5} \mathrm{H}_{4}\right) \mathrm{Re}(\mathrm{CO})_{3}$ in $\mathbf{8}$ relative to the phenyl group in $\mathbf{2}$.

We studied the agonist-antagonist effect of compound $8(\boldsymbol{Z}+\boldsymbol{E})$ on cell lines derived from breast cancer tumours (MVLN, MDA-MB231) (Table 1). In the MVLN line recently 
developed by Pons ${ }^{14}$ it has been shown that the expression of the luciferase gene is proportional to the oestrogenic effect of the product tested. It contains a high level of ER $\alpha$ while the MDA-MB231 line does not contain any. In these tests, the control value is set by definition at $100 \%$. For any given product, a value above $100 \%$ indicates an oestrogenic effect, and a value below $100 \%$ an anti-oestrogenic effect. As usual oestradiol is used as the reference for oestrogens and hydroxytamoxifen $\mathbf{2}(\boldsymbol{Z}+\boldsymbol{E})$ for anti-oestrogens. The results obtained with MVLN cells show that the Re complex 8 behaves as an anti-oestrogen with almost identical efficacy as $\mathbf{2}$. The observed effect with $\mathbf{8}$ is certainly hormonally based, since it is abolished by addition of oestradiol into the medium (values in square brackets in the Table). On MDA-MB231 cells which do not possess ER $\alpha$ but may possess ER $\beta,{ }^{15} 8$ and 2 have no effect. It thus appears that the observed antiproliferative effect is dependent on the oestradiol receptor $\alpha$, as is also the case with tamoxifen.

Table. Antiproliferative activity of compounds $\mathbf{8 , 2}$ and $\mathbf{E}_{\mathbf{2}}$ on different cell lines.

\begin{tabular}{|c|c|c|c|}
\hline \multirow{2}{*}{ Compound } & \multirow{2}{*}{ Molarity (M) } & MVLN $^{\text {a) }}$ & MDA-MB231 $^{\text {b) }}$ \\
\cline { 2 - 4 } & & & $\mathrm{nd}$ \\
\hline $\mathbf{8}$ & $1 \times 10^{-6}$ & $55.5[97]^{\mathrm{c}}$ & 91 \\
\cline { 2 - 4 } & $1 \times 10^{-7}$ & $51.5[101]^{\mathrm{c}}$ & 88 \\
\hline $\mathbf{2}$ & $1 \times 10^{-7}$ & 51.5 & 91 \\
\hline $\mathbf{E}_{2}$ & $1 \times 10^{-10}$ & 258 & \\
\hline
\end{tabular}

a) Cells with a high level of ER $\alpha$. Results are expressed as percentage of the luciferase induction after $24 \mathrm{~h}$ of culture. ${ }^{14}$

b) Cells with no ER $\alpha$, but presumably with ERß. ${ }^{15}$ Results are expressed as the percentage of DNA/control after $120 \mathrm{~h}$ of culture. ${ }^{16}$

c) Value obtained after simultaneous addition in the medium of $10 \mathrm{nM}_{\text {of }} \mathrm{E}_{2}$.

It appears that $\mathbf{8}$ may have a higher potential as an organometallic radiopharmaceutical, despite the fact that up to now the chelate route has been the one explored with tamoxifen; ${ }^{17}$ in the latter case the ER binding rate was found to be too small to measure, which was not the case with $\mathbf{8}$. It is therefore important to find a rapid route by which to attach useful isotopes of Tc and Re to 8 . To this end, we plan to use a selective photochemical decomplexation reaction that we have recently discovered, followed by rapid 
recomplexation in water with a new reagent reported by Alberto, ${ }^{18,19}\left(\mathrm{H}_{2} \mathrm{O}\right)_{3} \mathrm{M}^{+}(\mathrm{CO})_{3}$ with $\mathrm{M}$ $={ }^{99 \mathrm{~m}} \mathrm{Tc},{ }^{188} \mathrm{Re}$.

\section{Notes and references}

† Procedure for the preparation of $\mathbf{7}$ and $\mathbf{8}$. Titanium tetrachloride (2 $\mathrm{ml}, 18 \mathrm{mmol})$ was added dropwise to a suspension of zinc powder $(2.34 \mathrm{~g}, 36 \mathrm{mmol})$ in $60 \mathrm{ml}$ of THF at $0{ }^{\circ} \mathrm{C}$. The mixture obtained was heated at reflux for $2 \mathrm{~h}$ and then cooled to rt. A second solution was prepared by dissolving 4-(4-bromobutoxy)-4A-hydroxybenzophenone (4.25 g, $6 \mathrm{mmol}$ ) and cyclopentadienyltricarbonylrhenium ethyl ketone (2.35 g, $6 \mathrm{mmol})$ in $30 \mathrm{ml}$ of THF. This latter solution was added dropwise to the first one and then the resulting mixture was heated for $2 \mathrm{~h}$. After cooling to rt, the mixture was stirred with water and $\mathrm{CH}_{2} \mathrm{Cl}_{2}$. After treatment the pure oily $Z+E$ mixture of 7 was obtained with a yield of $62 \%$; MS (IE, $70 \mathrm{eV}$ ) $\mathrm{m} / \mathrm{z}$ : 708 $\left(\mathrm{M}^{+}\right.$.), $624(\mathrm{M}-3 \mathrm{CO})^{+}$. Halide 7 (3 mmol) and a solution of dimethylamine in $\mathrm{MeOH}$ (2 M, $15 \mathrm{ml}, 30 \mathrm{mmol}$ ) were heated with stirring in an autoclave at $60^{\circ} \mathrm{C}$ for 1 day. After cooling, the solution was concentrated under reduced pressure. After treatment the pure amines $8(Z+$ $\boldsymbol{E}$ ) were isolated as oil containing a mixture of $Z$ and $E$ isomers with a yield of 64\%; MS (IE, $70 \mathrm{eV}) \mathrm{m} / \mathrm{z}$ : $673\left(\mathrm{M}^{+}\right.$.). The $Z$ and $E$ isomers were separated on reverse phase preparative Kromasil C18 column, solvent $\mathrm{MeOH}$ phosphate buffer $\left(\mathrm{KH}_{2} \mathrm{PO}_{4}, 25 \mathrm{mM}\right.$, pH 7) 80/20, flow rate $6 \mathrm{~mL} \mathrm{~min}^{-1}$. The retention times obtained on an analytical column of the same type (Kromasil C18, $10 \mu \mathrm{M}, 250 \mathrm{~mm}$ ) are repectively of $19.4 \mathrm{~min}$ for $\mathbf{8 Z}$ and $26.4 \mathrm{~min}$ for $\mathbf{8 E}$ in the proportion 48.5/51.5. Selected data for the two isomers: $8 \boldsymbol{E}$ : mp $153{ }^{\circ} \mathrm{C},{ }^{1} \mathrm{H}$ NMR $\delta 7.04$ (d, $\left.J=8.4 \mathrm{~Hz}, 2 \mathrm{H}, \mathrm{H}_{\text {arom }}\right), 6.93$ (d, $J=8.4 \mathrm{~Hz}, 2 \mathrm{H}, \mathrm{H}_{\text {arom }}$ ), 6.78 (d, $J=8.4 \mathrm{~Hz}, 2 \mathrm{H}, \mathrm{H}_{\text {arom}}$ ), 6.70 (d, $J=8.4 \mathrm{~Hz}, 2 \mathrm{H}, \mathrm{H}_{\text {arom }}$ ), ${ }^{13} \mathrm{C}$ NMR $\delta$ (all aromatic carbons) 135.5 (C), 134.6 (C), 130.6 (2 CH), 130.1 (2 CH), 129.9 (C), 115.6 (2 CH), 114.1 (2 CH). 8Z: mp 134 ${ }^{\circ} \mathrm{C},{ }^{1} \mathrm{H}$ NMR $\delta 7.00$ (d, $J=8.4 \mathrm{~Hz}, 2 \mathrm{H}, \mathrm{H}_{\text {arom }}$ ), 6.99 (d, $J=8.4 \mathrm{~Hz}, 2 \mathrm{H}, \mathrm{H}_{\text {arom }}$ ), 6.75 (d, $J=8.4 \mathrm{~Hz}, 2 \mathrm{H}, \mathrm{H}_{\text {arom}}$ ), 6.74 (d, $J=8.4 \mathrm{~Hz}, 2 \mathrm{H}, \mathrm{H}_{\text {arom}}$ ), ${ }^{13} \mathrm{C}$ NMR (all aromatic carbons) $\delta 135.9$ (C), 134.8 (C), 130.5 (2 CH), $129.9(2 \mathrm{CH}+\mathrm{C}), 115.3(2 \mathrm{CH}), 114.3(2 \mathrm{CH})$.

$1 \quad$ K. Dhingra, Invest. New Drugs, 1999, 17, 285.

2 J. I. MacCregor and V. C. Jordan, Pharmacol. Rev., 1998, 50, 151.

3 M. Cognlan and M. Kort, Expert Opin. Ther. Patents, 1999, 9, 1524.

$4 \quad$ V. C. Jordan, J. Nat. Cancer Inst., 1998, 90, 967. 
5 A. Houlton, R. Roberts and J. Silver, J. Organomet. Chem., 1991, 418, 107.

$6 \quad$ P. Köpf-Maier, Eur. J. Clin. Pharmacol., 1994, 47, 1.

$7 \quad$ J. R. Dilworth and S. J. Parrott, Chem. Soc. Rev., 1998, 27, 43.

8 G. Jaouen, A. Vessières, S. Top and R. Alberto, J. Organomet. Chem., 2000, 600, 23.

9 G. Jaouen, S. Top, A. Vessières, G. Leclercq, J. Quivy, L. Jin and A. Croisy, C. R. Acad. Sci. Paris, 2000, Série IIc, 89.

10 S. Top, J. Tang, A. Vessières, D. Carrez, C. Provot and G. Jaouen, Chem. Commun., 1996, 955.

11 S. Gauthier, J. Mailhot and F. Labrie, J. Org. Chem., 1996, 61, 3890.

12 S. Top, B. Dauer, J. Vaisserman and G. Jaouen, J. Organomet. Chem., 1997, 541, 355.

13 A. Vessières, S. Top, A. A. Ismail, I. S. Butler, M. Louer and G. Jaouen, Biochemistry, 1988, 27, 6659.

14 M. Pons, D. Gagne, J. C. Nicolas and M. Mehtali, Bio Techniques, 1990, 9, 450.

15 G. G. J. M. Kuiper, E. Enmark, M. Pelto-Huikko, S. Nilsson and J.-A. Gustafsson, Proc. Natl. Acad. Sci. USA, 1996, 93, 5925.

16 G. Leclercq, N. Devleeschouwer and J. C. Heuson, J. Steroid Biochem., 1983, 75.

17 D. H. Hunter and L. G. Luyt, Bioconjugate Chem., 2000, 11, 175.

18 R. Alberto, R. Schibli, A. Egli, A. P. Schubiger, U. Abram and T. A. Kaden, J. Am. Chem. Soc., 1998, 120, 7987.

19 S. Top, E. B. Kaloun and G. Jaouen, J. Am. Chem. Soc., 2000, 122, 736.

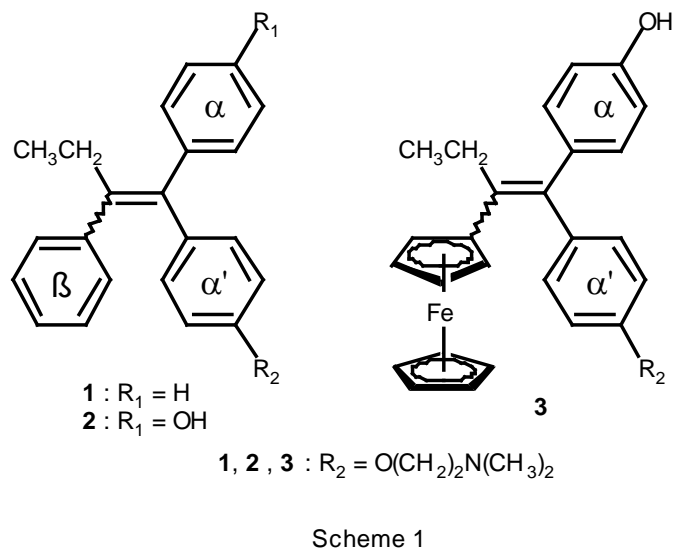



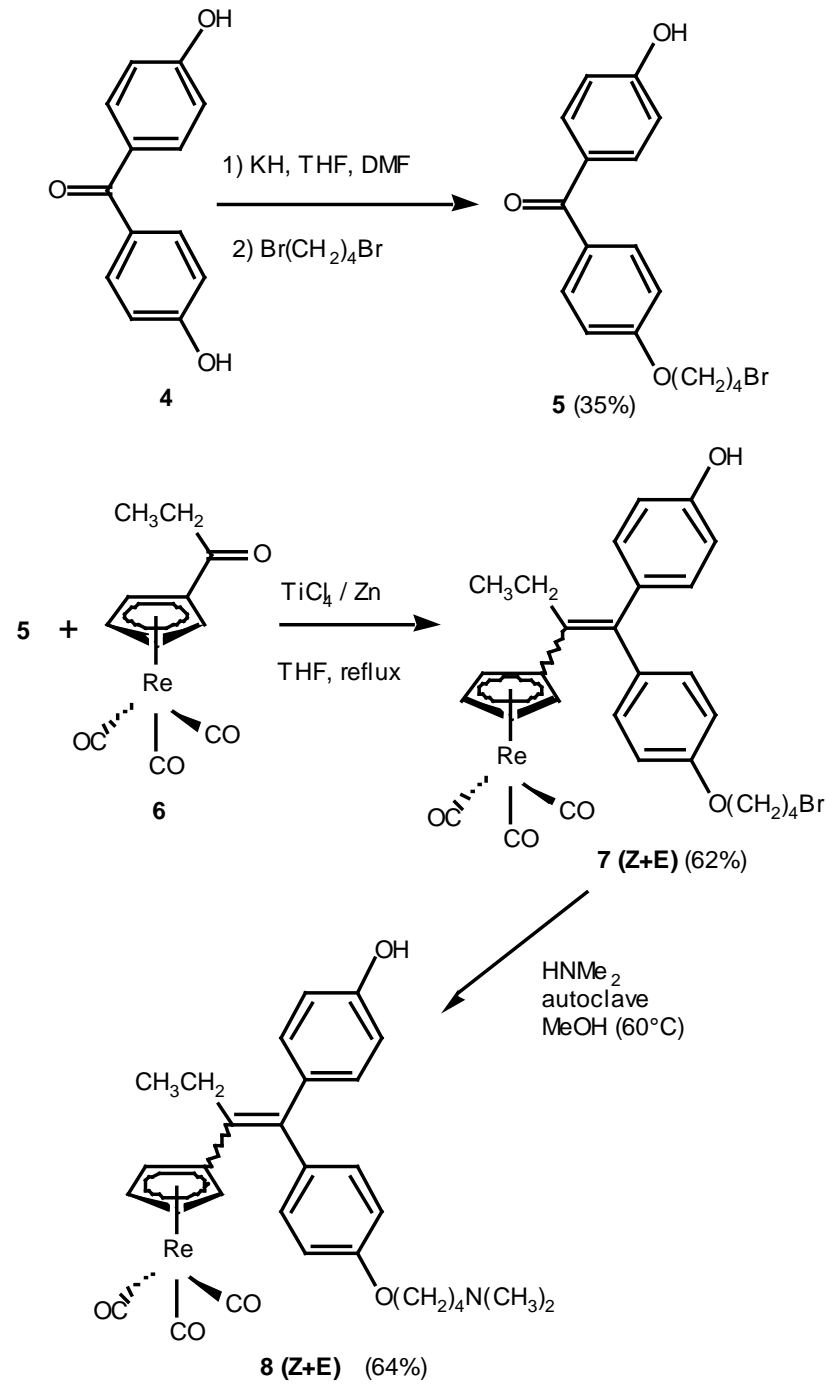

Scheme 2 